\title{
Recent Update
}

\section{Accounting Standards in India}

Gurminder Kaur Arora

\begin{abstract}
Associate Professor, Sri Guru Gobind Singh College of Commerce, University of Delhi, Pitampura, New Delhi 110034, India; gurminderkaur@sggscc.ac.in
\end{abstract}

Received: 10 July 2021

\section{Introduction}

International Financial Reporting Standards (IFRSs) is a set of high quality, understandable, enforceable and globally accepted 'principle-based' accounting standards for the preparation of financial statements (Parvathi, 2017) $)^{1}$. Accounting standards deal with recognition, measurement and presentation of events and transactions and their disclosure requirements. Over the years, accounting standards have been developed by different accounting authorities. The basic purpose of accounting standards is to establish a common set of procedures and rules in reporting Financial Statements, so as to facilitate understanding between and among the preparers and users of accounting information.

The onset of globalisation, and increasing interdependence among the world nations through cross border flows of goods, services, human resources, capital, information and culture has called for radical changes in the international accounting and reporting. Visible as increases in Foreign Direct Investment and Foreign Institutional Investment, cross - border mergers and acquisitions, franchising and Business Outsourcing as examples of international transactions, have led to Integration of the global capital market and necessitated the unification of financial reporting methods and the accounting structure. Keeping this in mind, during the last decade, accounting professionals and accounting bodies across the globe, have tried to put in place a financial reporting system which is harmonised, robust and has extensive applicability.

\subsection{History and Evolution of International Accounting Standards}

The evolution of International Accounting Standard began in 1966 with a suggestion to set up a world - wide study group. The following year, the Accountants' International Study Group was formed, and it began to publish papers on various accounting topics, some of which became the
Published: 15 Nov 2021 foundation for accounting standards that eventually came into force.

In 1973, International Accounting Standard Committee (IASC) was set up with the objective of developing accounting standards which would be followed internationally. The IASC issued a series of standards called the International Accounting Standards (IAS), named and numbered from IAS 1 to IAS 41. From the late 1990s, companies in European and Asian countries were allowed to use International Accounting Standards (IAS) as a substitute for their respective domestic accounting standards. Further, between 1973 to 2000, IASC developed a comprehensive list of accounting standards and interpretations, a conceptual framework and other guidance notes called the International Accounting Standards (IAS Standards) and its interpretations were called the 'SIC' (Standing Interpretations Committee). The objectives of the Interpretation Committee are to interpret the application of IAS, provide timely guidance on financial reporting issues that are not specifically addressed in IAS and undertake other tasks at the request of International Accounting Standard Board (IASB).

The growth of IASC as the major global standard setter, however started in 2000s. In 2001, the IASB, formed under the International Financial Reporting Standards (IFRS) Foundation, replaced the former standard setting body - the International Accounting Standards Committee (IASC). The IASB, a full time London based, independent, privately funded organisation, consists of board members who are accounting experts drawn from all over the world, who are well versed in standard-setting and academic work. The IASB announced that it would follow the standards already issued by IASC and SIC interpretations, but stated that any new standard would be known as part of the series called the International Financial Reporting Standards and interpretations would be called IFRIC (International Financial Reporting Interpretations Committee), evolved by the IFRS Foundation. The IFRS Foundation, an independent, non- 
profit organisation, raises funds from banks and other organisations that desire to have international accounting standards in place in all the countries.

International Financial Reporting Standards (IFRSs) is a set of high quality, understandable, enforceable and globally accepted 'principle-based' accounting standards for the preparation of financial statements. The IASB, an independent standard-setting body of the IFRS Foundation, is responsible for the development and publication of IFRS by following a thorough, open and transparent process in close connection with the stake holders around the world. The IFRS are published by the IASB, an independent standard-setting organisation based in London.

The IFRS convergence has gained momentum all over the world and India is no exception. As the world is going global on a massive scale, the need for convergence seems to be crucial. The need for common accounting standards have been felt all over the world, and as of date, around 100 countries such as those from Australia, European Union, Russia, have either adopted fully or have converged IFRS standards with their own standards and the number is expected to increase further in coming years. Many other countries are replacing their domestic standards with IFRS's while some other countries are adopting the approach of first reviewing the IFRS's, ensuring compatibility with their economic, political and social conditions and then adopting them, with or without any changes. The ultimate aim of convergence is to have common acceptable standards, which is practiced worldwide, ensuring transparency and utility of financial information.

\subsection{Accounting Standards: A Typology}

Broadly, there are two sets of accounting standards that are accepted for international use namely, Generally Accepted Accounting Principles (GAAP) system, which is rules-based accounting method used in United States and the International Financial Reporting Standards (IFRS) which are principle-based, which establish broad rules rather than defining specific treatments. GAPP are diverse in nature but based on a few basic principles which include consistency, relevance, reliability and comparability. GAAP are rules, conventions, procedures and standards that are accepted in a community (Preethi et al., 2015) ${ }^{2}$. However, these principles vary in different locations. For example, US GAAP is only applicable in US, it consists of rules and standards established by Financial Accounting Standard Board (FASB).

In 2002, IASB and Financial Accounting Standard Board (FASB), the body supporting US GAAP, announced a programme aimed at eliminating differences between IFRS and US GAAP.

There are two ways available to a country to comply with IFRS: (1) Adoption of IFRS in its original form, or (2) Convergence with IFRS. The major boost to the standards came in the year 2002 with 25-nations member of the European Union making it mandatory for EU-registered companies to adopt IFRS by 2005. In 2005, European Union made it mandatory for publicly traded companies to present consolidated financial statements in conformity with IFRS starting from January 01, 2005. IFRS provided the European members with a ready-made, high quality set of accounting standards, which largely replaced their existing conflicting national accounting standards. Further, adoption of IFRS by Australia, New Zealand, Hong Kong and South Africa provided momentum for the world-wide adoption of IFRS. The adoption was supported by many international organisations, including the G20, World Bank, International Monetary Fund, Basel Committee (Jain, 2011) ${ }^{3}$.

In 2008, FASB conceded that US could no longer function in the global economy by prescribing American rules for other countries to follow. Thus, it allowed foreign companies access to US capital markets while reporting under IFRS. Until this move, any company wanted to get listed on the New York Stock Exchange or any other US exchange, had to engage in high-cost reconciliation between its IFRS-compliant financial records and the results under GAAP in 2012. The SEC announced that it expected separate US GAAP to continue for some more time but sought to encourage further work to align the two standards. The difference in compliance of these standards are due to different market environment factors and structures of corporate governance in which IFRS is implemented. IFRS are considered as "Principle-based" set of standards (in fact they establish broad rules rather than defining specific treatments) whereas US GAAP follow a 'rule-based approach'.

The IFRS include:

- International Financial Reporting Standards (IFRSs) - developed by IASB;

- International Accounting Standards (IASs) adopted by IASB; 
- Interpretations originated from the International Financial Reporting Interpretations Committee (IFRICs); and

- Standing Interpretations Committee (Gupta, 2017)

The major capital markets without an IFRS mandate are:

i. The US, with no current plans to change;

ii. Japan, where voluntary adoption is permitted but not required; and

iii. China, which intends to fully converge at some time.

The evolution of IFRS around the globe has been summarised in Figure 1.

\subsection{Accounting Standards in India}

In 1949, the Indian Government, in order to streamline the accounting practices in the country, established the Institute of Chartered Accountants in India (ICAI) by passing the ICAI Act, 1949. Subsection (3A) to Section 211 of the Companies Act 1956, required that every company's profit and loss account and balance sheet complied with accounting standards. Accounting
Standards not only prescribe accounting treatment of complex business transactions but also provide greater transparency and market discipline. These accounting standards were defined as rules issued by ICAI in consultation with National Advisory Committee on Accounting Standards (NACAS) established under the Companies Act 1956. NACAS was brought in Companies Act 1956 in 1998-99. Before that, AS promulgated by ICAI's Accounting Standard Board (ASB) were applicable. The force of those AS were limited as ICAI members were expected to report the non-compliance while forming opinion under an Audit Report. However, with the advent of NACAS and promulgation of Companies (Accounting Standards) Rules, 2006, AS got statutory force whereby Managements/Companies were mandatorily required to follow those while doing Financial Reporting. NACAS, a body of experts including representatives of various regulatory bodies and government agencies, has been engaged in examining and advising implementation of accounting standards framed by ASB of ICAI (Indian Accounting Standards, 2020) ${ }^{6}$.

Recognising the need to synchronise the various accounting policies and practices, the ICAI as the premier accounting body, set up the ASB on $21^{\text {st }}$ April, 1977 to harmonise the diverse accounting policies and practices

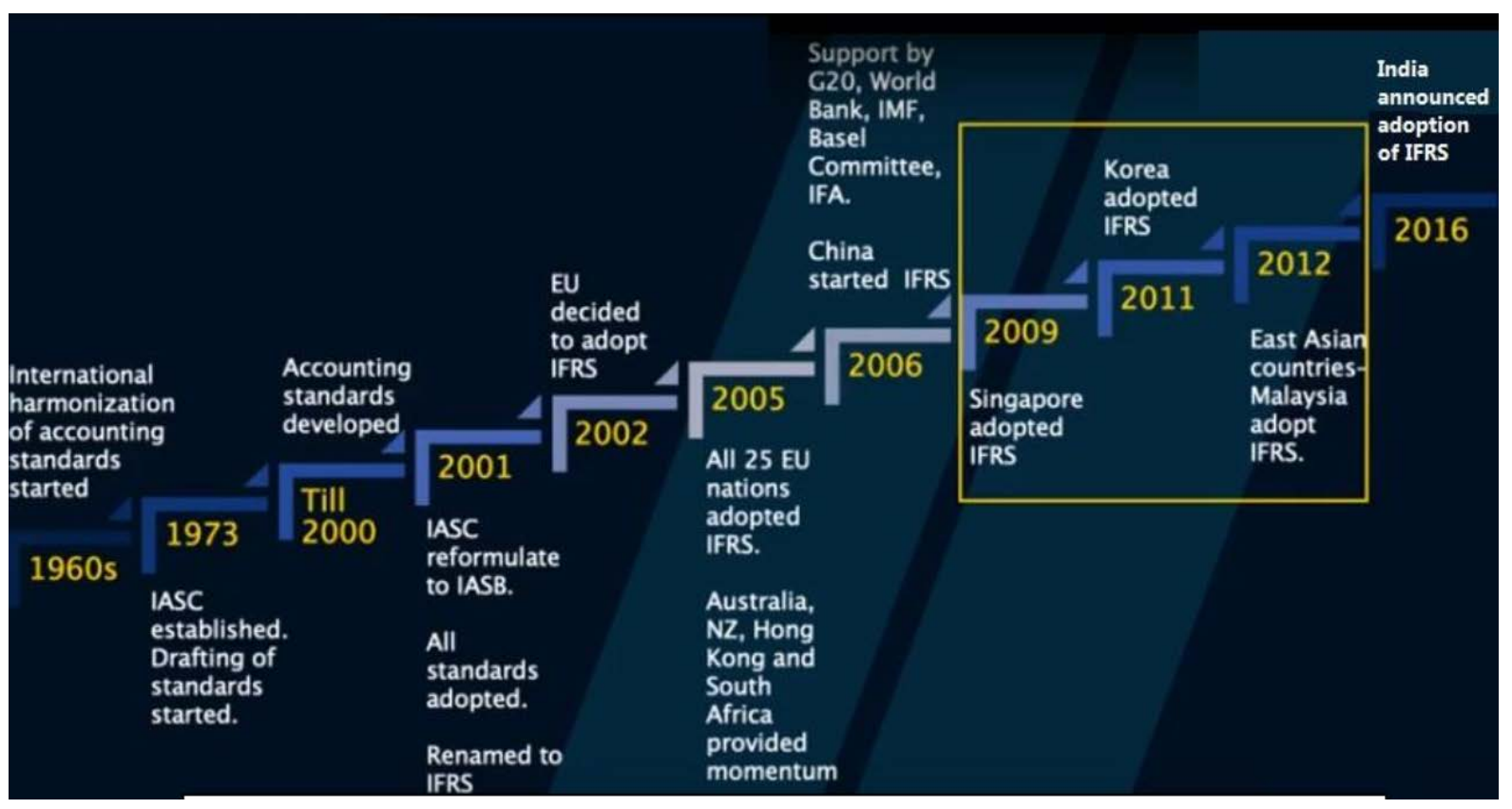

Source: Adhana (2020) $)^{5}$

Figure 1. Evolution of International Financial Reporting Standards. 
prevalent in our country. The board consisted of the members from the Company Law Board, Central Board of Direct Taxes, Central Board of Excise and Customs, Controller General of Accounts, Security Exchange Board of India, Comptroller and Auditor General of Accounts, University grants Commission, Educational and Professional Institution, Councils of the Institute and representatives of the industry. The primary duty of ASB was to formulate the accounting standards for India. These standards could be established by the Council of the Institute in India. During the formation of accounting standards, the ASB considered the applicable laws, usage, customs and business environment existing in our country. For this purpose, ASB took the valued views and guidelines from various industrial houses, government and other interested parties.

Keeping in mind resource dependency and continuous interaction with the outside world, major emphasis on alignment of its practiced accounting standards with the rest of the world gained momentum since 1991, as part of initiative to liberalise Indian economy and attract foreign participation in technology, business and investment. As the United States was the major source of such resources, India aligned its accounting standards with US GAAP to meet the pre-condition of transparency in financial reporting by foreign investors. It also provided ICAI with experience and knowledge of bringing such changes in the accounting standards, governance, training and regulatory framework.

Thereafter, the NACAS constituted under Section 210A through Companies Amendment Act, 1999, reviewed such standards and recommended them to the Government of India. The Government then considered the recommendations of the NACAS and on accepting them, notified the standards under the Indian Companies Act, 1956 by publishing them in the Official Gazette. Initially, the Accounting Standards were only recommendatory in nature. However, after insertion of Section 211(3C) by the Companies Amendment Act, 1999, compliance with notified Accounting Standards has been made mandatory. As of year 2000, 32 Accounting Standards (AS) have been issued by the ICAI, numbered AS- 1 to AS-7 and AS-9 to AS-32 (AS-6 and AS-8 is no longer in use since it was merged with AS-10 and AS-26 respectively). Before the constitution of NACAS, the Institute was the sole accounting standard setter in India. However, NACAS is not an independent body, it can consider only accounting standards recommended by ICAI and advise the
Government of India to notify them under the Companies Act (Indian Accounting Standards, 2020) ${ }^{6}$.

\subsection{Convergence with IFRS}

In the year 2006, ICAI initiated the process of moving towards IFRS with a view to enhance acceptability and transparency of the financial information communicated by the Indian corporates through their financial statements. This move was subsequently accepted by the Government of India. The decision was made to converge and not to adopt IFRS issued by IASB. The decision of convergence in place of adoption was made after detailed analysis of IFRS requirement and extensive discussion with the stake holders. Accordingly, while formulating IFRS-converged Indian Accounting Standards, efforts have been made to keep these standards, as far as possible, in line with the corresponding IAS/IFRS and departures have been made where considered absolutely necessary. It was decided to have two separate sets of Accounting Standards viz;

i. Indian Accounting Standards converged with IFRS called Ind AS; and

ii. Existing Notified Accounting Standards

A task force was set up by ICAI with the objective to lay down a road map for convergence of IFRS in India. The idea of mitigating to Ind AS was to facilitate:

- The capital flows in India.

- Global recognition of our Balance Sheet;

- Movement of accounting professionals across the world; and

- International acquisitions and consolidation of financial statement of multi-national enterprises operating in India and Indian enterprises operating abroad.

India officially decided in 2007 to converge with IFRS. The ASB finalised the "Concept Paper on Convergence with IFRSs in India" after considering the suggestion of Council of ICAI. The ICAI started the process of developing new set of accounting standards that are based on and converged with IFRS, referred to as 'Indian Accounting Standards (Ind As)'. The ICAI and IASB then decided to work together, collaborate and develop quality and comparable accounting standards instead of adopting the IFRS completely. They started the process of 
developing new set of accounting standards that are based on and converged with IFRS; referred to as Ind AS.

As part of convergence plan, the ICAI classified IFRS into the following four categories:

- Category I: IFRS which can be adopted immediately or in near future as they have no or minor differences with the corresponding Indian AS (e.g., Construction Contracts, Borrowing Costs, Inventories, Cash Flow Statements).

- Category II: IFRSs which may require some time to reach a level of technical preparedness by the industry and professionals keeping in view the existing economic environment and other factors (e.g., Investment Property, Share-based Payment).

- Category III: IFRSs having conceptual differences with the corresponding Indian AS that should be discussed with the IASB (e.g., Investments in Associates, Joint Ventures, Provisions and Contingent Liabilities).

- Category IV: IFRSs, the adoption of which would require amendments in laws/regulations (e.g., Accounting Policies, Property, Plant \& Equipment, First Time Adoption of IFRS) (Aggarwal, 2019) $\stackrel{8}{ }$.

It was accepted that adding disclosure requirements or removing optional treatments as per local environment conditions does not lead to non-compliance with IFRS. Thus, in Indian context, convergence with IFRS means adoption of IFRS with necessary modifications to reflect Indian conditions. The Ind AS are basically the standards that have been harmonised with the IFRS to make reporting by Indian companies more globally accessible. Since Indian companies have a far wider global reach now as compared to earlier times, the need to converge reporting standards with international standards was strongly felt, which resulted in introduction of Ind AS.

In pursuance of commitment given by the then Prime Minister of India, Dr. Manmohan Singh in G-20 Summit held in Pittsburgh in September 2009, 35 Ind AS converged with IFRS were notified by the Ministry of Corporate Affairs, Government of India (MCA) and placed on the website of MCA in February 2011. The Ind AS were supposed to come into force on $1^{\text {st }}$ April, 2011. However, the implementation of these standards got postponed for various procedural, operational and tax issues. For a smooth transition to IFRS, ICAI took up the matter of convergence with NACAS and various regulators such as Reserve Bank of India (RBI), Securities and Exchange Board of India (SEBI), Insurance Regulatory and Development Authority (IRDA) and Central Board of Direct Taxes. IASB, the issuer of IFRS also supported ICAI in its endeavour towards convergence.

In a move to converge with IFRS, certain provisions have been incorporated in the new Companies Act 2013 which came into effect in September 2013. As per section 129(3), the Act mandates consolidated Financial Statements for any company having a subsidiary, associate or a joint venture. The Act has also given cognizance to the Ind AS considering their applicability in future. In the budget speech in July 2014, the then Honourable Finance Minister Mr. Arun Jaitley had stated that:

"There is an urgent need to converge Indian Accounting standards with the International Financial Reporting Standards (IFRS). I propose the adoption of new Indian Accounting Standards (Ind AS) by the Indian companies from the financial year 2015-16 voluntarily and from the financial year 2016-17 on a mandatory basis. Based on international consensus, the regulators will separately notify the date for implementation of Ind AS for the banks, Insurance companies etc. Standards for computation of tax shall be notified separately" (Indian Accounting standards, $2020)^{6}$.

The MCA notified the Companies (Indian Accounting Standards (Ind AS)) Rules 2015, which stipulated the adoption and applicability of 39 accounting standards (Ind AS) for companies other than banking companies, insurance companies and Non-banking Finance Companies (NBFCs) in a phased manner starting from $1^{\text {st }}$ April, 2015, being voluntary date of adoption of Ind AS. While these standards are similar to IFRS in many respects, some exemptions/changes have been made in the process of convergence to some of them which may result in significant differences between IFRS and Ind AS for some companies. With reference to Ind AS, it was said accounting of entities under common control is termed as "carve-in" and differences which are in deviation to the accounting principles and practices stated in IFRS are commonly known as "carve-outs".

Ind AS = IFRS + Carve outs - Carve in + Removal of Options 
Carve out - In some cases, Indian Accounting Standards uses a different treatment for accounting vis-à-vis the one used in case of IFRS (items removed from IFRS/IAS while making Ind AS).

Carve in - An additional guidance is inserted in Ind AS which is not there in IFRS (Additional items in Ind AS over IFRS/IAS).

Removal of Options - It means that for some IFRS, the choice for accounting treatment is available but for some standards in Ind AS, those choices have been removed (Adhana, 2020) .

The application of Ind AS is based on the listing status and net worth of the company. The mandatory application of Ind AS has been restricted to listed and unlisted companies with a net worth of INR 500 crores and above from the accounting period beginning on or after $1^{\text {st }}$ April, 2016. With effect from $1^{\text {st }}$ April, 2017, all listed and unlisted companies having a net worth of INR 250 crores and above would be required to prepare their financial statements as per applicable Ind AS. Banking companies and NBFCs are also required to implement Ind AS on $1^{\text {st }}$ April 2018 onwards based on their criteria of net worth. The MCA has since issued three Amendment Rules, one each in year 2016, 2017, 2018 to amend the 2015 Rules (Figure 2).

\section{The Road Ahead}

The basic guidelines for convergence of Ind AS are as follows:

- The date and manner of calculating net worth has been defined. It has to be calculated based on standalone financial statements of the company as on $31^{\text {st }}$ March, 2014 or first audited period ending thereafter. Net worth defined is similar to definition given in section 2(57) of Companies Act, 2013. It will be total paid-up share capital, reserves created out of profits (except revaluation and amalgamation reserves) and security premium after deducting accumulated losses, deferred or miscellaneous expenses if any;

- Once Ind AS are applied voluntarily or mandatorily, it is irrevocable and not required to prepare another set of financial statements as per AS;
- Companies not covered by the roadmap to continue to apply existing standards;

- Application is for both standalone as well as consolidated financial statements if threshold criteria is met;

- Companies meeting the thresholds (net-worth less than 250 crores) for the first time at the end of accounting year shall apply Ind AS from the immediate next accounting year;

- Overseas subsidiaries, joint ventures and associates of an Indian Company which is covered under new Ind AS rule are not required to prepare their standalone financial statements as per Ind AS. However, consolidated accounts should be as per Ind AS; and

- In case of conflict with Ind AS and Law, the provisions of Law shall prevail and financial statements should be prepared in conformity with it (Indian Accounting Standards, 2020) ${ }^{6}$.

The ICAI is making all efforts to make sure that these standards are implemented in the same spirit in which they are formulated. Phase I and Phase II companies have already published/ in the process of publishing their financial statements as per Ind AS. A complete set of financial statements prepared in compliance with the IFRS would ideally comprise of the following:

i. A Statement of Financial Position as at the end of the period; more commonly known as "Balance Sheet";

ii. A Statement of Profit and Loss for the year and the statement of other comprehensive income. Other comprehensive income would include those items of income/expenses that are not recognised in the profit and loss account to comply with the other relevant standards. Both these statements may either be combined or shown separately;

iii. A Statement of Changes in Equity. This would include a reconciliation between accounts shown at the beginning and at the end of the year;

iv. A Statement of Cash Flows for the period; and

v. Notes to the financial statements including a summary of significant accounting policies followed and other explanatory information (Mishra, 2014) ${ }^{7}$. Currently, 39 Ind AS have become operational, out of which 23 have been converged from IAS and the rest 16 have been converged from IFRS (Figure 3 and Table 1). 


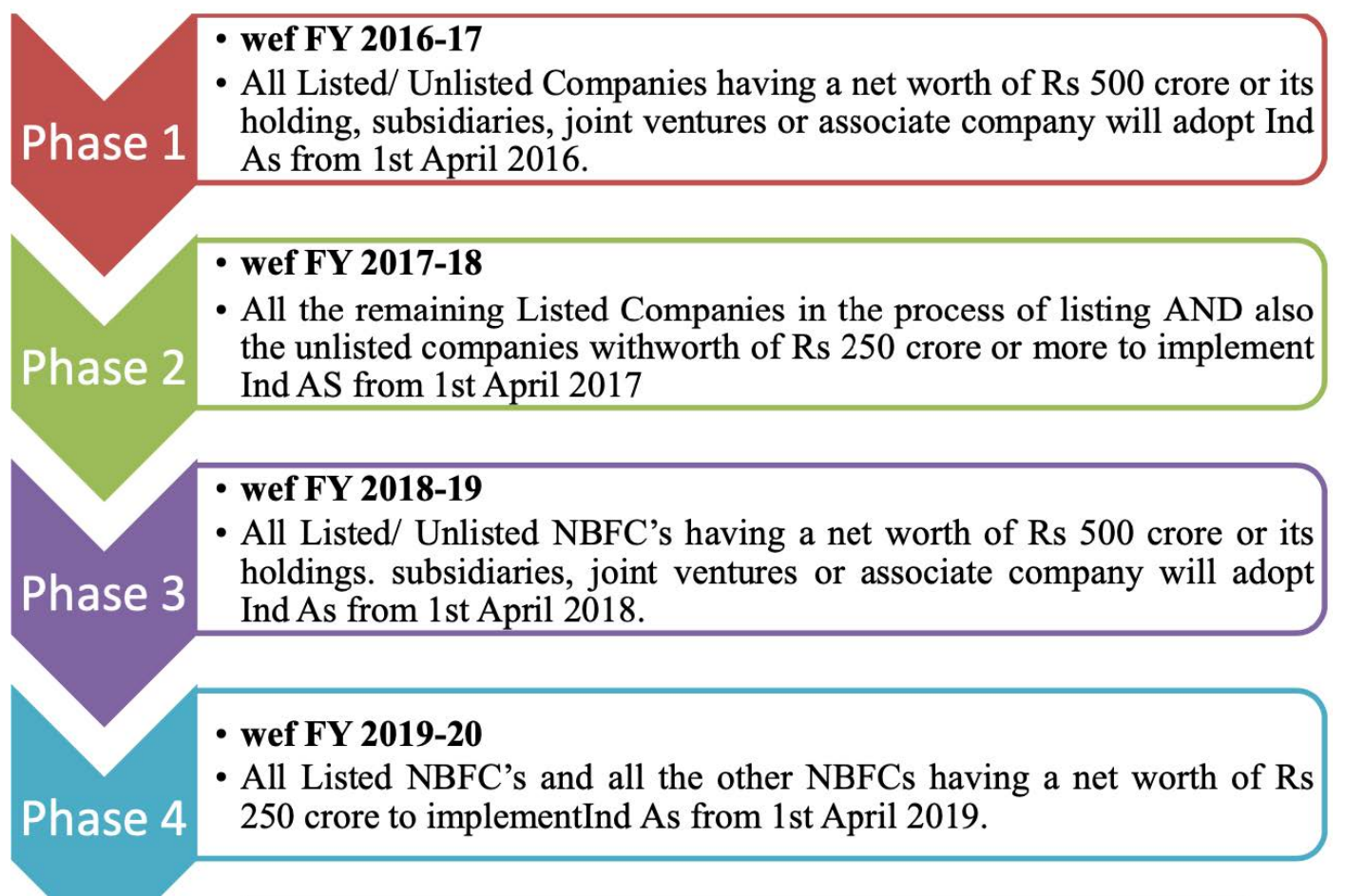

Source: Adhana (2020)

Figure 2. Roadmap of International Financial Reporting Standards in India.
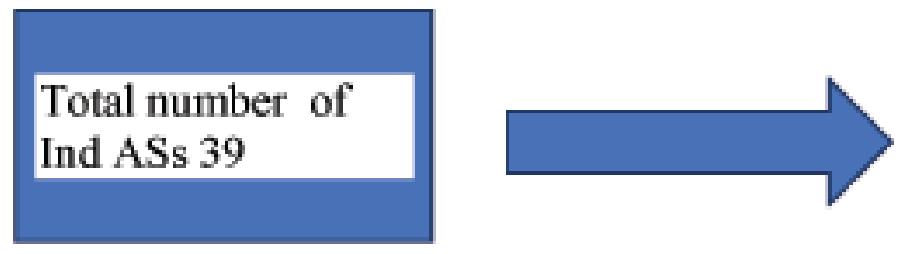

\section{$23+16$ Ind}

ASs(convergerd from IAS \& IFRS

\section{Interpretations (as appendices to respective Ind ASs)}

Figure 3. Indian Accounting Standards (Ind AS).

Reserve Bank of India, vide its circular dated April $5^{\text {th }}, 2018$ deferred the implementation of Ind AS for scheduled Commercial Banks (SCBs) excluding Regional Rural Banks (RRBs) by one year, to be made effective from $1^{\text {st }}$ April, 2019. However, vide circular dated $22^{\text {nd }}$ March, 2019, the implementation of Ind AS for SCBs has been deferred until further notice. As per Insurance Regulatory and development Authority (IRDA) circular dated $28^{\text {th }}$ June 2017, all insurance companies in India are required to adopt Ind AS from $1^{\text {st }}$ April, 2020. However, the IRDA has decided to defer the implementation of Ind AS in the insurance sector till further notice (until the IASB issues final amendment to IFRS 17). Additionally, insurance companies are no longer required to submit proforma Ind AS financial statements to IRDAI on quarterly basis, as was required earlier (Indian accounting Standards, 2020).

Recently, certain amendments have been made in IFRS/IAS issued by IASB. The ICAI, to keep up the pace with the global developments, revised the notified Ind AS in line with the amendments made in IFRS/IAS issued 
Table 1. The List of Indian Accounting Standards converged from IAS/IFRS is as follows

\begin{tabular}{|c|c|c|}
\hline S. No. & Ind ASs & Name of Ind AS (Converged from IAS) \\
\hline 1. & Ind AS 1 & Preparation of Financial Statement \\
\hline 2. & Ind AS 2 & Inventories \\
\hline 3. & Ind AS 7 & Statement of cash flows \\
\hline 4. & Ind AS 8 & Accounting Policies, changes in Accounting Estimation and Events \\
\hline 5. & Ind AS 10 & Events after the Reporting Period \\
\hline 6. & Ind AS 12 & Income Taxes \\
\hline \multirow[t]{3}{*}{7.} & Ind AS 16 & Property, Plant and Equipment \\
\hline & Ind AS 17 & Leases (Superseded Ind AS 116, effective $1^{\text {st }}$ April 2019) \\
\hline & Ind AS 18 & Revenue (Superseded by Ind AS 115 , effective $1^{\text {st }}$ April 2018) \\
\hline 8. & Ind AS 19 & Employee benefits \\
\hline 9. & Ind AS 20 & Accounting for government Grants and Disclosure of Government Assistance \\
\hline 10. & Ind AS 21 & The Effects of Changes in Foreign Exchange Rates \\
\hline 11. & Ind AS 23 & Borrowing Costs \\
\hline 12. & Ind AS 24 & Related Party Disclosures \\
\hline 13. & Ind AS 27 & Separate Financial Statements \\
\hline 14. & Ind AS 28 & Investments in Associates and Joint Ventures \\
\hline 15. & Ind AS 29 & Financial Reporting in Hyperinflationary Economics \\
\hline 16. & Ind AS 32 & Financial Instruments: Presentation \\
\hline 17. & Ind AS 33 & Earnings Per Share \\
\hline 18. & Ind AS 34 & Interim Financial Reporting \\
\hline 19. & Ind AS 36 & Impairment of Assets \\
\hline 20. & Ind AS 37 & Provisions, Contingent liabilities and Contingent Assets \\
\hline 21. & Ind AS 38 & Intangible Assets \\
\hline 22. & Ind AS 40 & Investment property \\
\hline 23. & Ind AS 41 & Agriculture \\
\hline 24. & Ind AS 101 & First-time adoption of Indian accounting Standards \\
\hline 25. & Ind AS 102 & Share Based Payments \\
\hline 26. & Ind AS 103 & Business Combinations \\
\hline 27. & Ind AS 104 & Insurance Contracts \\
\hline 28. & Ind AS 105 & Non-Current Assets held for sale and Discontinued Operations \\
\hline 29. & Ind AS 106 & Exploration for and Evaluation of Mineral resources \\
\hline 30. & Ind AS 107 & Financial Instruments: Disclosures \\
\hline 31. & Ind AS 108 & Operating Segments \\
\hline 32. & Ind AS 109 & Financial Instruments \\
\hline 33. & Ind AS 110 & Consolidated Financial statements \\
\hline 34. & Ind AS 111 & Joint Arrangements \\
\hline 35. & Ind AS 112 & Disclosure of Interests in Other Entities \\
\hline 36. & Ind AS 113 & Fair Value Measurement \\
\hline 37. & Ind AS 114 & Regulatory Deferral Accounts \\
\hline 38. & Ind AS 115 & Revenue from Contacts and Customers (effective for period beginning on/after $1^{\text {st }}$ April 2018) \\
\hline 39. & Ind AS 116 & Leases (effective for period beginning on/after $1^{\text {st }}$ April 2019) \\
\hline
\end{tabular}

Source: Matta $(2021)^{9}$. 
Table 2. IFRS Convergence Ind AS: Implementation Roadmap- ${ }^{\text {st }}$ April, 2020

\begin{tabular}{|c|l|l|}
\hline PHASE & $\mathbf{1}^{\text {ST }}$ Ind AS (FY) & Categories of Companies Covered \\
\hline 1 & $2015-16$ & Voluntary-Any company can apply Ind AS for their Financial Statements \\
\hline 2 & $2016-17$ & $\begin{array}{l}\text { Mandatory-Companies other than Banking, NBFC and Insurance } \\
\text { (a) Listed with Net worth 500 crores or more } \\
\text { (b) Unlisted with Net worth 500 crores or more } \\
\text { (c) Parent, Subsidiary, Associates and Joint ventures of above entities }\end{array}$ \\
\hline 3 & $2017-18$ & $\begin{array}{l}\text { Mandatory-Companies other than Banking, NBFC and Insurance } \\
\text { (a) All listed companies not covered in phase } 1 \\
\text { (b) Unlisted companies with Net worth 250 crores or more }\end{array}$ \\
\hline 4 & $2018-19$ & NBFCs with Net worth 500 crores or more \\
\hline 5 & $2019-20$ & $\begin{array}{l}\text { (a) All listed NBFCs not covered in phase 3 } \\
\text { (b) Unlisted NBFCs with Net worth Rs 250 to 500 crores }\end{array}$ \\
\hline 6 & $2020-21^{\star}$ & Insurance Companies \\
\hline 7 & Not Yet decided ${ }^{* *}$ & All Scheduled Commercial Banks (except RRB and UCB) \\
\hline
\end{tabular}

Note: ${ }^{*}$ In January 2020, IRDA deferred implementation of Ind AS until the finalisation of IFRS 17 by IASB.

${ }^{*}$ In March 2019, RBI deferred implementation until further notice. In April 2018-19, RBI had deferred Ind AS implementation for banks for $1^{\text {st }}$ year from 2018-19.

Source: Indian Accounting Standards (2020).

by IASB. MCA has notified the amendments to the Ind AS vide notification dated July 24, 2020 as Companies (Indian Accounting Standards) amendment Rules, 2020, comprising critical amendments to Ind AS which are applicable for accounting year beginning on or after 1st April, 2020. The position of implementation of IFRS convergence into Ind AS as on $1^{\text {st }}$ April 2020 is shown in Table 2.

\section{Conclusion}

To provide our country with robust, high quality internationally accepted accounting standards, Institute of Chartered Accountants has spearheaded the implementation of IFRS - converged Indian Accounting Standards which are issued by Union Government of India under the supervision and control of Accounting Standard Board (ASB) of ICAI and in consultation with NACAS. Financial reporting in India has undergone a momentous transformation owing to the adoption of Ind AS. It has enhanced the comparability of financial statements and enabled Indian companies to participate in global capital markets. This paradigm shift has made the Indian financial reporting framework at par with the global standards of reporting. ICAI is playing a vital role in convergence of Indian Accounting Standards at par with the globally accepted Accounting Standards.
Ind AS has become a reality now with Phase I and Phase II companies having already published their financial statements as per Ind AS. Transition to Ind AS has improved the transparency and comparability of the financial statements.

However, Ind AS involves application of several new and complex concepts, which require a significant level of judgement and estimation, accompanied by detailed qualitative and quantitative disclosures. The ICAI is making all efforts to ensure that standards are implemented in the same spirit in which they have been formulated. The Ind AS implementation group has been making relentless efforts to make this transition smooth and effective through its various endeavours. For this purpose, the group has formulated educational materials covering various issues for reference of its users. For addressing transition related queries in a timely manner, Ind AS Technical Facilitation group (ITFG) has been formed by the Accounting Standard Board, which is working hard to provide timely clarifications to members, preparers, users and other stakeholders. Queries raised are also addressed through Support - desk for implementation of Ind AS. Apart from this, the group is working actively to organise Certificate Courses on Ind AS, conduct in-house training programs for regulatory bodies such as C\&AG, IRDAI, CBDT etc and also organise seminars, web casts on Ind AS for corporate entities. 


\section{References}

1. Parvathi, P. R. IFRS Convergence: Opportunities and Challenges in India. Accounting and Financial Control. 2017; 1(2): 13-18. http://dx.doi.org/10.21511/ afc.01(2).2017.02

2. Preethi, S., Deepti, M. \& Rawat, D. S. Challenges and Prospects of IFRS in Indian Accounting Systems. International Journal of Core Engineering and management. 2015; 142-149.

3. Jain, P. IFRS Implementation in India: Opportunities and Challenges, Research gate. 2011.

4. Gupta, Pallavi (2017) IFRS Convergence in India: A Conceptual Study of Journey. International Journal of Current Research. April 2017; (4): 49034-49041.
5. Adhana, Deepak Kumar. Convergence of International Financial Reporting Standards (IFRS) In Indian Accounting Curriculum. Alochana Chakra Journal. 2020. ISSN NO:2231-3990

6. Indian Accounting Standards (Ind AS). An Overview, Publication by The Institute of Chartered Accountants of India (ICAI). 2020.

7. Mishra, S.K. (2014): Strategies, Benefits, and Challenges of Adoption of IFRS in India. International Journal of Accounting and Financial Management Research (IJAFMR). Dec 2014; 4(6): 17-26. ISSN(P): 2249-6882.

8. Aggarwal, Priyanka. IFRS in India. Research Gate. 2019

9. Matta, A. Ind AS Certification Course- Session 1. Slide share; May, 2021. 